\title{
Influence of physical exercise on $\beta$-amyloid, $\alpha$-synuclein and tau accumulation: an in vitro model of oxidative stress in human red blood cells
}

\author{
C. IOFRIDA'A,A, S. DANIELE',A, D. PIETROBONO ${ }^{1, A}$, J. FUSI², F. GALETTA², \\ U. BONUCCELLI', M.L. TRINCAVELLI', F. FRANZONI'², C. MARTINI' \\ ${ }^{7}$ Department of Pharmacy, University of Pisa, Pisa, Italy; \\ ${ }^{2}$ Department of Clinical and Experimental Medicine, University of Pisa, Pisa, Italy; \\ A These authors equally contributed to the present work.
}

\begin{abstract}
A B S T R A C T
A common pathological feature of neurodegenerative disorders (NDs), such as Alzheimer's (AD) and Parkinson's $(P D)$ diseases, is the accumulation and misfolding of specific proteins, primarily $\alpha$-synuclein $\left(\alpha\right.$-syn), $\beta$-amyloid ${ }_{1-42}$ $(A \beta)$ and tau, in brain and in peripheral tissues too. Oxidative stress has been proved to be involved in NDs at various levels and, in particular, in such protein alterations, on the contrary physical activity is emerging as a counteracting factor in NDs.

In the present work, the content of $A \beta, \alpha$-syn and tau in red blood cells (RBCs) derived from ten endurance athletes $(A T H L)$ and ten sedentary volunteers (SED) were compared before and after in vitro oxidative stress treatment.

Total A $\beta, \alpha-s y n$ and tau were quantified in RBCs (isolated from the subjects) by immunoenzymatic assays. Oxidative stress was induced by in vitro $\mathrm{H}_{2} \mathrm{O}_{2}$ administration to RBCs.

$\mathrm{H}_{2} \mathrm{O}_{2}$ treatment was confirmed to significantly enhance $\mathrm{ROS}$ accumulation in RBCs. Total A $\beta$ content in RBCs was lower in the ATHL subgroup with respect to the SED one. In the SED subgroup, but not in the ATHL one, total A $\beta$ levels were increased by oxidative stress. Total $\alpha$-syn content was lower in the ATHL subgroup with respect to the $S E D$ one and $\alpha$-syn levels were increased by oxidative stress in both subgroups, with the percentage of increase higher in SED. Total tau content was comparable in both ATHL and SED and it was not affected by oxidative stress.

Our data confirm previous findings evidencing that both oxidative stress and sedentary style contribute to aberrant folding and accumulation of NDs-related proteins, pointing to the importance of both anti-oxidant therapies and exercising in the prevention and treating of such diseases.
\end{abstract}

\section{Key words}

Oxidative stress $\bullet$ Protein accumulation $\bullet$ Neurodegenerative diseases $\bullet \alpha$-synuclein $\bullet \beta$-amyloid $\bullet$ Tau $\bullet$ Physical exercise

\section{Introduction}

Oxidative stress is induced by an excess of formation of Reactive Oxygen Species (ROS), caused by an imbalance between their generation and elimination by the biological system (Ienco et al., 2011). Among its various effects, oxidative stress plays a key role in aging (Poon et al., 2004) and in its related neurodegenerative disorders (NDs) (Gandhi and Abramov, 2012; Patten et al. 2010), as an excess of Reactive Oxygen Species (ROS) can lead to cellular damage and death (Fulda et al., 2010), as well as to mitochondrial dysfunction in neurons (Fulda et al., 2010; Federico et al., 2012; Navarro and Boveris, 2010). As a consequence, antioxidant therapies are becoming increasingly important in the treatment 
of age-related NDs (Feng and Wang, 2012; Singh, 2015; Ienco et al., 2011).

In NDs, such as Alzheimer's disease (AD), Parkinson's disease (PD) and amyotrophic lateral sclerosis, there is pathological evidence of a progressive neuronal loss (Parihar and Hemnani, 2004; Bartels and Leenders, 2009; Román, 1996) and reactive gliosis (Dalle-Donne et al., 2006; Klein et al., 2004) in specific brain areas, in which aggregating misfolded proteins form highordered insoluble fibrils in neurons and/or glial cells (Dalle-Donne et al., 2006; Klein et al., 2004; Ugalde et al., 2016). For example, accumulation of $\alpha$-synuclein $(\alpha$-syn) has been established to form Lewy bodies and neurites in PD and dementia with Lewy bodies (DL) and glial cytoplasmic inclusions in multiple system atrophy (Goedert et al., 2013). In AD, there are senile plaques containing extracellular deposits of $A \beta$ and intra-neuronal neurofibrillary tangles composed of hyperphosphorylated tau protein (Maurer et al., 1997). However, postmortem evaluation has shown a mixed pattern of proteinopathies, commonly accompanied by signs of chronic cerebrovascular disease pathology. The potential contribution of $\alpha$-syn to AD pathogenesis is emerging (Larson et al., 2012; Marsh and BlurtonJones, 2012), with 30-40 \% of AD cases presenting Lewy bodies and Lewy neurites (Trojanowski, 2002). Literature data suggest that $A \beta$, tau and $\alpha$-syn promote the accumulation and/or aggregation of one another (Lee et al., 2004). Alterations in protein folding related to NDs are not restricted to the brain, thus extensive research has been conducted on biological changes and putative biomarkers in other tissues or in cerebrospinal fluid (CSF) (Growdon, 1999; Garlind et al., 1999; Hock et al., 2000; Hampel et al., 2001; Andreasen et al., 2001; Giacomelli et al., 2017). The use of blood has gradually emerged, due to its availability and low cost and to the time effectiveness of the method (Reiber, 2003).

Oxidative stress is also involved in aberrant protein aggregation in NDs (Chen et al., 2012), as A $\beta$ deposition in $\mathrm{AD}$ participates in a positive feedback loop in which oxidative stress leads to increased $\mathrm{A} \beta$ generation and, conversely, $\mathrm{A} \beta$ polymerization generates oxidative stress (Zhang et al., 1997; Zhao and Zhao, 2013); in addition, ROS promote tau phosphorylation (Zhao and Zhao, 2013).

It has been demonstrated that regular exercise benefits brain function and cognition by exerting effects at multiple levels, from neurons to inter-regional cerebral pathways (Voss et al., 2013), including an increase in capillarization and proteolytic degradation of toxic oligomers (Johnson and Mitchell, 2003; Power et al., 2013). Physical activity has been demonstrated to up-regulate the enzymatic antioxidant system and to enhance the physiological response to oxidative damage, thus leading to a recovered redox state of brain cells (Radak et al., 2016). Exercising not only improves cognitive functions in healthy subjects (Kramer et al., 2003; Colcombe et al., 2004; Weuve et al., 2004; Winter et al., 2007; Hindin and Zelinski, 2012; Dishman et al., 2006) but also reduces the risk of developing age-related neurodegenerative diseases like dementia or AD (Laurin et al., 2001; Abbott et al., 2004; Larson et al., 2006; Paillard et al., 2015) and PD (Paillard et al., 2015). In addition, it seems to slow down the progress of such diseases, thus constituting a potential nonpharmacological therapeutic treatment (Kwok et al., 2016; Cusso, Donald and Khoo, 2016; Jakowec et al., 2016; Bernardo et al., 2016). It has been demonstrated that physical activity reduces beta-amyloid levels and amyloid deposition in transgenic mice (Lazarov et al., 2005) and recent work has shown that voluntary running counteracts $\mathrm{A} \beta$ deposition and tau phosphorylation in a mouse model of AD (Tapia-Rojas et al., 2016). In humans, it has been found that performers of higher levels of physical activity have lower $\mathrm{A} \beta$ plasma levels and brain depositions (Brown et al., 2013).

On the whole, literature data have proved there is a link between oxidative stress, neurodegeneration and physical exercise. Recently, our data demonstrated the correlation among plasma antioxidant capability (AOC), the primary marker of oxidative stress in agingrelated pathologies (Pandey and Rizvi, 2010), physical exercise and the peripheral levels of $\alpha$-syn, tau and $A \beta$ in a cohort of young and older athletes and sedentary subjects (Daniele et al., 2017). Herein the accumulation of such ND-related proteins was investigated in a RBC model of oxidative stress. The cellular response to oxidative stress was compared among SED and ATHL in order to verify if physical exercise could exert a protective effect. RBCs constitute a good model to study aging-related biochemical alterations, including protein misfolding (Brown et al., 2013; Kiko et al., 2012; Wang et al., 2015). The contents of $A \beta, \alpha$-syn and tau in RBCs derived from ten endurance athletes and ten sedentary volunteers were compared before and after in vitro oxidative stress treatment. 


\section{Methods}

\section{Materials}

Recombinant human $A \beta, \alpha$-syn were obtained from Sigma Aldrich, Milan, Italy. Antibodies against A $\beta$, $\alpha$-syn and tau were from Santa Cruz Biotechnology.

\section{Study population and setting of the study}

The study population consisted in ten endurance athletes (ATHL, mean age 33.6 \pm 3.4 years), recruited from the Sport Medicine Unit of the Department of Clinical and Experimental Medicine of the University of Pisa, and ten age-sex-matched sedentary volunteers (SED, mean age 36.7 \pm 3.5 years) were studied (Table 1). Athletes performed endurance exercise more than three times/week and were also active in national road-running races.

All subjects were healthy, as assessed by clinical history, physical examination, basal and stress electrocardiography, blood chemistry, hematology and urine analysis. Major criteria for inclusion were as followed: total plasma cholesterol ranging from 3.1 to $5.8 \mathrm{mmol} / \mathrm{L}$, HDL cholesterol from 0.67 to 1.9 $\mathrm{mmol} / \mathrm{L}$, plasma triglycerides from 0.34 to $1.7 \mathrm{mmol} / \mathrm{L}$, body mass index lower than $30 \mathrm{~kg} / \mathrm{m}^{2}$, diastolic arterial blood pressure lower than $90 \mathrm{mmHg}$ and systolic arterial blood pressure lower than $140 \mathrm{mmHg}$.

The level of intensity of physical activity for each participant was evaluated by the 15-point Borg RPE scale (Borg, 1982; Hamer and Slocombe, 1997). The scale ranges from 6 to 20, with 6 corresponding to no exertion at all, 7.5 to extremely light, 9 to very light, 11 to light, 13 to somewhat hard, 15 to hard, 17 to very hard, 19 to extremely hard, and 20 to maximal exertion. This study was approved by the Ethics Committee of the Great North West Area of Tuscany (271/2014 to F.F.) and it was carried out in accordance with the Declaration of Helsinki. All subjects gave informed consent to participate in the study. Fully informed consent was obtained from each subject entering the study.

\section{RBCs collection}

Whole blood (total volume: $6 \mathrm{ml}$ ) was collected from the subjects into a tube containing EDTA as an anticoagulant. RBCs were separated from plasma by a centrifugation at $200 \times \mathrm{g}$ at $4{ }^{\circ} \mathrm{C}$ for 10 minutes and the RBC pellet was centrifuged at $1000 \mathrm{x} \mathrm{g}$ for $10 \mathrm{~min}$ and washed three times with PBS, then frozen at $-20{ }^{\circ} \mathrm{C}$ until use. For immunoenzymatic assays, the RBC pellets were resuspended to have $40 \mathrm{mg}$ total protein/100 $\mu \mathrm{l}$.

\section{Detection of total $A \beta$}

$\mathrm{A} \beta$ levels in blood samples were measured using an immunoenzymatic assay, as described previously (Pesini et al., 2012). The plate was pre-coated o.n. at $4^{\circ} \mathrm{C}$ with a specific antibody to $\mathrm{A} \beta$ (Santa Cruz, sc-9129). After extensive washing with PBS-T, nonspecific sites were blocked with $1 \%$ BSA. RBCs $(0,2$ $\mathrm{mg} / 100 \mu \mathrm{l})$ were added to each well and incubated at $25^{\circ} \mathrm{C}$ for one hour. After extensive washing with PBS-T, samples were detected using the polyclonal antibody to A $\beta$ (sc-5399, Santa Cruz Biotechnology). The standard curve was constructed using recombinant human $A \beta$ solutions at eight different concentrations.

\section{Detection of total $\alpha$-synuclein}

Total $\alpha$-synuclein was detected in RBCs following literature's protocols (Foulds et al. 2011). Briefly, wells were pre-coated o.n. at $4^{\circ} \mathrm{C}$ with a full length polyclonal antibody to $\alpha$-syn (sc-10717, Santa Cruz Biotechnology), and non-specific sites were blocked using Bovine Serum Albumine (BSA) for $1 \mathrm{~h}$ at $37^{\circ} \mathrm{C}$. RBCs $(0,150 \mathrm{mg} / 100 \mu \mathrm{l})$ were captured on wells for $2 \mathrm{~h}$ at $25^{\circ} \mathrm{C}$. Purified recombinant protein standards of $\alpha$-syn were assayed in parallel with human samples to generate a standard curve. After extensive washing, samples were probed with a mouse monoclonal antibody to $\alpha$-syn (Santa Cruz, sc-12767), and subsequently with an anti-mouse-HRP antibody. The wells were then washed 4 times with PBS-T (phosphate buffered saline containing 0.01\% Tween 20), before adding the enzyme substrate TMB (3,3',5,5'-tetramethylbenzidine, Thermo Scientific) and leaving the colour to develop for $30 \mathrm{~min}$ at room temperature. Absorbance values at $450 \mathrm{~nm}$.

\section{Detection of total tau}

Tau levels in blood samples were measured using an immuno-enzymatic assay, as described previously (Pesini et al., 2012). The plate was pre-coated overnight at $4^{\circ} \mathrm{C}$ with a specific antibody to tau (Santa Cruz, sc-32274). After extensive washing with PBS-T, non-specific sites were blocked with $1 \%$ BSA. RBCs $(0,5 \mathrm{mg} / 100 \mu \mathrm{l})$ were added to each well and incubated at $25^{\circ} \mathrm{C}$ for one hour. After extensive washing with PBS-T, samples were 
Tab. 1. - Descriptive analysis of the total population and of the subgroups. The data are the mean $\pm S D$.

\begin{tabular}{|c|c|c|c|c|c|}
\hline & $\begin{array}{c}\text { Number } \\
\text { of subjects (N) }\end{array}$ & Age (y) & BMI & Heart rate & $\begin{array}{c}\text { Physical activity } \\
\text { level }\end{array}$ \\
\hline ATHL & 10 & $33.6 \pm 3.4$ & $23,6 \pm 1,9$ & $52,0 \pm 3,0$ & $14,2 \pm 2,2 * * *$ \\
\hline SED & 10 & $36.7 \pm 3.5$ & $24,8 \pm 1,3$ & $60,1 \pm 5,3$ & $6,0 \pm 0,5$ \\
\hline BMI, Body Mass Index; ATHL, Athletes, SED, sedentary. ${ }^{*} * * P<.001$ vs sedentary subgroups. \\
\hline
\end{tabular}

detected using the polyclonal antibody to tau (sc5587, Santa Cruz Biotechnology). The standard curve was constructed using recombinant human tau solutions at eight different concentrations.

\section{In vitro model of oxidative stress}

RBCs were isolated from whole blood 8total volume: $6 \mathrm{ml}$ ) of the healthy subjects as described above. Cells were collected by centrifugation at $1100 \mathrm{~g}$ for 5 min, and suspended in DMEM-F12, containing $2 \mathrm{mM}$ L-glutamine, $2 \mathrm{mM}$ penicillin-streptomycin and $10 \%$ Foetal Bovine Serum. RBCs were counted using an automatic cell counter. Cells $\left(2 \times 10^{6}\right.$ cells/ sample) were seeded and treated with $1.5 \mathrm{mM}$ $\mathrm{H}_{2} \mathrm{O}_{2}$ for $16 \mathrm{~h}$. Following incubation, the cells were collected and resuspended to a final concentration of $80 \mathrm{mg} / 100 \mu \mathrm{l}$.

Levels of total $A \beta, \alpha$-syn and tau were quantified by immunoenzymatic assays reported above.

To confirm ROS activity upon $\mathrm{H}_{2} \mathrm{O}_{2}$ treatment, the fluorogenic dye 2,7-dichlorofluorescin diacetate $\left(\mathrm{H}_{2}\right.$ DCFDA, Molecular Probes, Invitrogen) was used (La Regina et al., 2013; Daniele et al., 2016). $\mathrm{RBCs}$ were seeded in black 96-multiwell plates (10 $\times 10^{3}$ cells/well), and incubated with $\mathrm{H}_{2} \mathrm{O}_{2}$ in DMEM without phenol red. One hour prior to treatment completion, $50 \mu \mathrm{M} \mathrm{H}$ DCFDA was added to the same media in the dark at $37{ }^{\circ} \mathrm{C}$. The fluorescence intensity (excitation $485 \mathrm{~nm}$ and emission $520 \mathrm{~nm}$ ) was normalized based on the number of cells stained with crystal violet (Daniele et al., 2016).

\section{Statistical analysis}

Analysis of variance was used to assess mean differences between subjects. Differences were considered significant at values of $p<0.05$. Data analysis from the in vitro model was performed using the $t$ test and one-way analysis of variance (ANOVA) with Bonferroni's corrected t tests for post-hoc pairwise comparisons (Daniele et al., 2016).

\section{Results}

\section{Descriptive statistics}

The variables of the two groups are reported in Table 1.

The subjects did not present significant differences in body mass index (BMI) and age. As expected, ATHL showed a lower resting heart rate than the sedentary. The level of physical activity of in the ATHL subgroup was significantly higher than the one of the sedentary (Table 1 ).

\section{In vitro model of oxidative stress}

$\mathrm{H}_{2} \mathrm{O}_{2}(2 \mathrm{mM}, 16 \mathrm{~h})$ was utilised in $\mathrm{RBCs}$ as an in vitro model of oxidative stress. As depicted in Figure $1, \mathrm{H}_{2} \mathrm{O}_{2}$ was confirmed to significantly enhance ROS accumulation in RBCs.

\section{Total $A \beta$ concentrations}

Total A $\beta$ levels were quantitatively measured in RBCs isolated from ATHL and SED.

As depicted in Figure 2A, the basal concentration of total $A \beta$ in $R B C$ s showed significantly lower values in the ATHL subgroup with respect to the SED one. In the sedentary subjects, total $A \beta$ levels were significantly higher following oxidative stress, whereas in ATHL oxidative stress did not significantly affect $A \beta$ accumulation.

These data suggest that the basal level of $A \beta$ in $\mathrm{RBCs}$ is modulated in vitro by oxidative stress and that a regular physical activity may be a protective factor toward oxidative stress-induced responses.

\section{Total $\alpha$-syn concentrations}

Total $\alpha$-syn levels were quantitatively measured in $\mathrm{RBCs}$ isolated from the two subgroups.

As depicted in Figure 2B, total $\alpha$-syn in RBCs showed significantly lower values in the ATHL subpopulation with respect to SED subjects, both in the presence and in the absence of oxidative stress. 


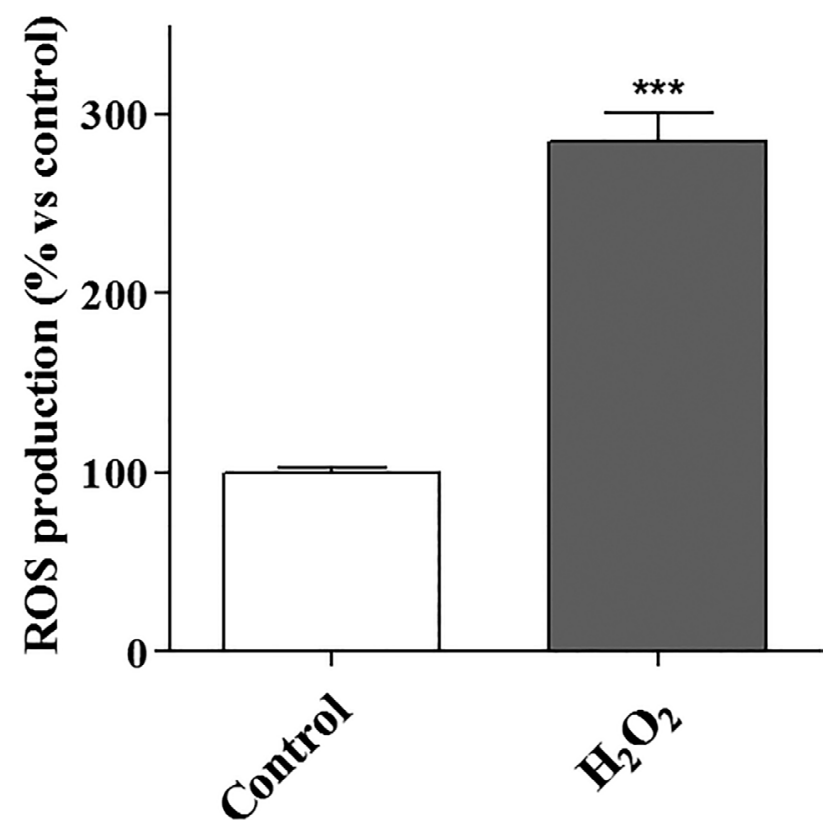

Fig. 1. - In vitro model of oxidative stress in RBCs obtained by $\mathrm{H} 2 \mathrm{O} 2$ ( $2 \mathrm{mM}, 16 \mathrm{~h}$ ) administration. Comparison of ROS accumulation between control and $\mathrm{H} 2 \mathrm{O} 2$-treated cells. ${ }^{* * *} \mathrm{P}<0.001 \mathrm{H} 2 \mathrm{O} 2$ versus Control.

In both groups, total $\alpha$-syn levels were significantly enhanced upon $\mathrm{RBC}$ treatment with $\mathrm{H}_{2} \mathrm{O}_{2}$.

These data suggest that RBC $\alpha$-syn concentrations can be modulated by oxidative stress independently of the physical exercise.

\section{Total tau concentrations}

As depicted in Figure 2C, Total tau in RBCs showed comparable levels in both ATHL and SED, suggesting that it is not modulated by physical activity, at least in our small cohort.

Moreover, total tau content in $\mathrm{RBCs}$ was not significantly modulated by $\mathrm{H}_{2} \mathrm{O}_{2}$ in the two groups, suggesting that $\mathrm{RBC}$ tau is not affected by oxidative stress.

\section{Discussion}

In the present work, the effects of oxidative stress and physical activity on the accumulation of ND-related proteins were evaluated in the RBCs of a group of twenty healthy subjects composed by ten endurance athletes and ten sedentary volunteers. Herein, it was confirmed that oxidative stress impacts $A \beta$ and $\alpha$-syn $\mathrm{RBC}$ contents in vitro and that the concentrations of these proteins could be differently modulated in relation to sedentary versus trained life style.

Oxidative stress is one of the putative common etiologies in various NDs, as it triggers mitochondrial dysfunction, cellular damage and DNA repair system impairment, all of which known to be key factors in accelerating both aging and ND development (Kim et al., 2015; Gandhi and Abramov, 2012; Patten et al., 2010). In particular, oxidative stress is related to the accumulation of misfolded proteins, such as $A \beta, \alpha$-syn and tau, which constitutes the neuropathological hallmark of $\mathrm{AD}, \mathrm{PD}$ and other neurodegenerative proteinopathies (Ugalde et al., 2016). For example, oxidative stress has been demonstrated to exacerbate $A \beta$ production and aggregation, as well as to promote tau phosphorylation, potentially inducing a vicious cycle of pathogenesis in AD (Kim et al., 2015; Zhao and Zhao, 2013). Mitochondrial dysfunction related to oxidative stress has been strongly associated with $\alpha$-syn accumulation and apoptosis of dopaminergic neurons in PD (Blesa et al., 2015).

Misfolded proteins related to NDs are hypothesized to accumulate in the brain even decades before the appearance of symptoms (Danev and $\mathrm{St}$ Stoyanov, 2010; Price et al., 2009). Recent studies have demonstrated a cell-to-cell transmission of pathologic $\mathrm{A} \beta$ and $\alpha$-syn in anatomically interconnected areas of the brain (Luk et al., 2012; Ridley et al., 2006). Brain, CSF and blood concentrations of such protein aggregates seem to be in a dynamic equilibrium (Kawarabayashi et al., 2001; Ghersi-Egea et al., 1996), suggesting that increased production in the brain could be associated with increased concentrations in the blood as the result of protein oligomers transfer across the blood brain barrier (Zlokovic, 2004; Eisele et al., 2010; DeMattos et al., 2001). Among blood cells types, RBCs seem to be particularly sensitive to oxidative stress and misfolded proteins (Wang et al., 2015; Kiko et al., 2012; Mohanty et al., 2014), exhibiting damage to cell membranes and decreased cell deformability, which is necessary for effective oxygen transport and delivery (Mohanty et al., 2014). Based on these findings, recent efforts to study RBC concentrations of misfolded proteins and their relationship with oxidative stress or NDs have emerged, including our recent work (Wang et al., 2015; Kiko et al., 2012; Daniele et al., 2017). 
A

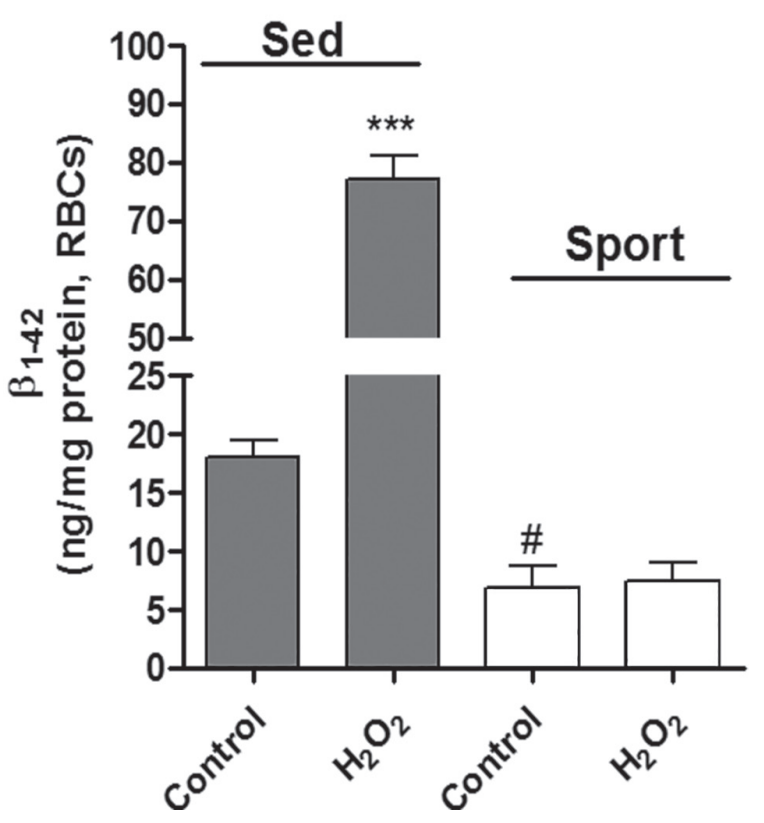

$\mathrm{C}$

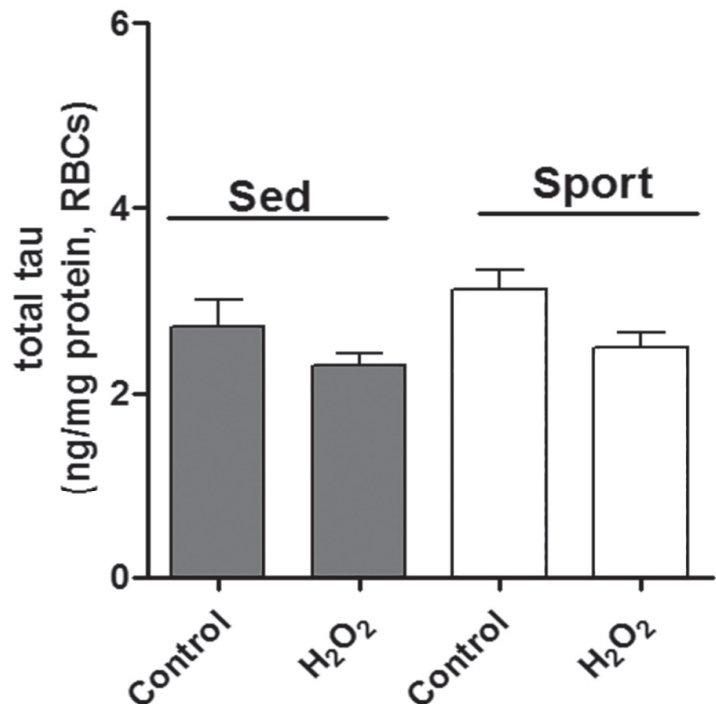

Fig. 2. - Accumulation of ND-related proteins in the in vitro model of oxidative stress. A-C RBC levels of total $A \beta$ (A), $\alpha$-syn (B) and tau (C) in a sedentary and athlete subject (mean $\pm \mathrm{SD}$ ). Lysates obtained from RBCs were subjected to specific immunoassay, as described in the Methods section. ${ }^{* *} \mathrm{P}<0.01,{ }^{* * *} \mathrm{P}<0.001 \mathrm{H} 2 \mathrm{O} 2$ versus Control; $\# \mathrm{P}<0.05, \# \# \# \mathrm{P}<0.001 \mathrm{ATHL}$ Control versus SED control.
B

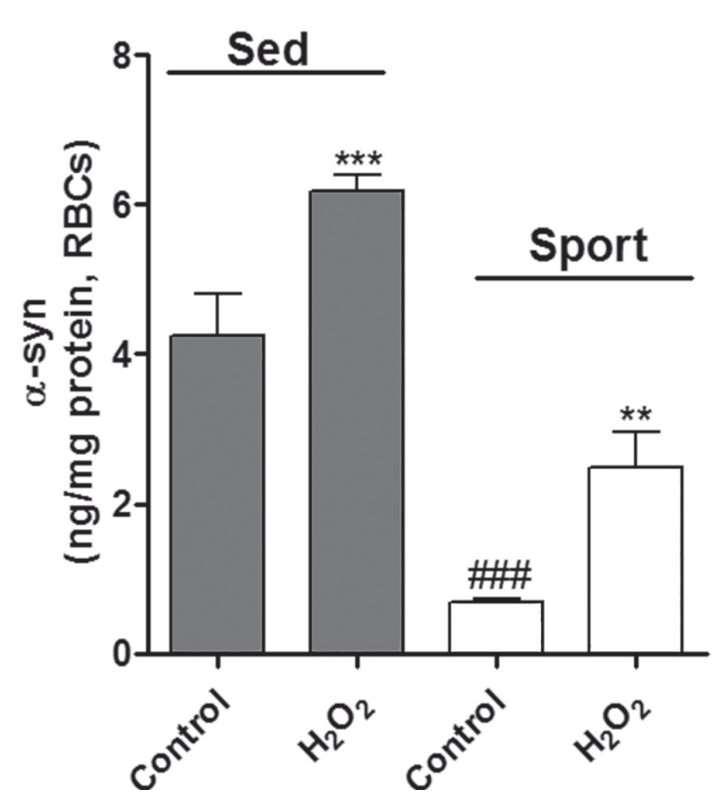

In this context, preliminary data have shown a correlation between $A \beta$ concentrations in the brain and RBCs (Brown et al., 2013; Wang et al., 2015), suggesting that these blood cells are a good model to study alterations in the brain.

In the present work, RBCs, isolated from twenty subjects, were used to measure the accumulation of $\mathrm{A} \beta, \alpha$-syn and tau, depending on oxidative stress and physical exercise, which is emerging as an important preventive and therapeutic tool in $\mathrm{AD}$ and PD (Mattson and Magnus, 2006; Radak et al., 2010). Consistent with previous findings (Head et al., 2012; Liang et al., 2010), in our study, in the SED subgroup, oxidative stress, induced in vitro by $\mathrm{H}_{2} \mathrm{O}_{2}$ administration, caused an increase in both $\mathrm{A} \beta$ and $\alpha$-syn concentrations, whereas in the athlete one it exerted the same effect on $\alpha$-syn content. For both proteins, levels were lower in the ATHL subgroup. In the whole sample, neither oxidative stress nor physical activity impacted tau levels.

In interpreting our results, the small sample size should be considered. Nevertheless, the present paper demonstrates the greater susceptibility of sedentary subjects versus athletes to oxidative stress, thus confirming the importance of investing effort in developing antioxidant therapies, as well as therapies based on physical exercise, in preventing 
NDs and also in delaying these diseases'progress. In addition, our work further highlights RBCs levels of NDs-related proteins as putative disease biomarkers.

\section{Funding}

This work was supported by PRA2016(539999_2015 to F.F) and Clinical research and innovation-scouting project" to C.M.

\section{Authors' contributions}

CI drafted the manuscript. SD, UB and MLT were involved with the conception, design, and interpretation of data. SD, DP, CI and JF performed the experiments. SD, DP, JF, FG, MLT and FF were involved with data analysis. SD and DP collected the clinical material. CM, MLT and UB provided general overall supervision of the study and acquired funding. All authors contributed to the drafting and critical revision of the manuscript and have given final approval of the version to be published.

\section{Abbreviations}

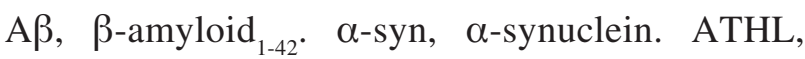
athletes subgroup. AD, Alzheimer's disease. NDs, neurodegenerative diseases. PD, Parkinson's disease. RBCs, red blood cells. ROS, reactive oxygen species. SED, sedentary subgroup.

\section{Ethics approval and consent to participate}

This study was approved by the Ethics Committee of the Great North West Area of Tuscany (271/2014 to F.F.) and it was carried out in accordance with the Declaration of Helsinki. All subjects gave informed consent to participate in the study.

\section{Availability of data and materials}

All data generated during this study are included in this published article. The original datasets analysed during the current study are not publicly available due to individual privacy.

\section{References}

Abbott R.D., White L.R., Ross G.W., Masaki K.H., Curb J.D., Petrovitch H. Walking and dementia in physically capable elderly men. JAMA, 292: 14471453, 2004.

Andreasen N., Minthon L., Davidsson P., Vanmechelen E., Vanderstichele H., Winblad B., Blennow K. Evaluation of CSF-tau and CSFAbeta42 as diagnostic markers for Alzheimer disease in clinical practice. Arch. Neurol., 58: 373379, 2001.

Bartels A.L., Leenders K.L. Parkinson's disease: the syndrome, the pathogenesis and pathophysiology. Cortex, 45: 915-921, 2009.

Bernardo T.C., Marques-Aleixo I., Beleza J., Oliveira P.J., Ascensão A., Magalhães J. Physical Exercise and Brain Mitochondrial Fitness: The Possible Role Against Alzheimer's Disease. Brain Pathol., 26: 648-663, 2016.

Blesa J., Trigo-Damas I., Quiroga-Varela A., JacksonLewis V.R. Oxidative stress and Parkinson's disease. Front. Neuroanat. 9: 91, 2015.

Borg G.A. Psychophysical bases of perceived exertion. Med. Sci. Sports Exerc. 14: 377-381, 1982.

Brown B.M., Peiffer J.J., Taddei K., Lui J.K., Laws S.M., Gupta V.B., Taddei T., Ward V.K., Rodrigues M.A.,

Chen X., Guo C., Kong J. Oxidative stress in neurodegenerative diseases. Neural Regen. Res., 7: 376-385, 2012.

Colcombe S.J., Kramer A.F., McAuley E., Erickson K.I., Scalf P. Neurocognitive aging and cardiovascular fitness: recent findings and future directions. J. Mol. Neurosci., 24: 9-14, 2004.

Cusso M.E., Donald K.J., Khoo T.K. The Impact of Physical Activity on Non-Motor Symptoms in Parkinson's Disease: A Systematic Review. Front. Med. (Lausanne), 3: 35, 2016.

Dalle-Donne I., Aldini G., Carini M., Colombo R., Rossi R., Milzani A. Protein carbonylation, cellular dysfunction, and disease progression. $J$. Cell. Mol. Med., 10: 389-406, 2006.

Danev S.I., St Stoyanov D. Early noninvasive diagnosis of neurodegenerative diseases. Folia Med (Plovdiv), 52: 5-13, 2010.

Daniele S., Da Pozzo E., Iofrida C., Martini C. Human Neural Stem Cell Aging Is Counteracted by $\alpha$-Glycerylphosphorylethanolamine. ACS Chem. Neurosci., 7: 952-963, 2016.p. 
Daniele S., Pietrobono D., Fusi J., Iofrida C., Chico L., Petrozzi L., Gerfo A.L., Baldacci F., Galetta F., Siciliano G., Bonuccelli U., Santoro G., Trincavelli M.L., Franzoni F., Martini C. $\alpha$-Synuclein Aggregates with $\beta$-Amyloid or Tau in Human Red Blood Cells: Correlation with Antioxidant Capability and Physical Exercise in Human Healthy Subjects. Mol. Neurobiol., doi: 10.1007/s12035-017-0523-5, 2017.

DeMattos R.B., Bales K.R., Cummins D.J., Dodart J.C., Paul S.M., Holtzman D.M. Peripheral anti-A beta antibody alters CNS and plasma A beta clearance and decreases brain A beta burden in a mouse model of Alzheimer's disease. Proc. Natl. Acad. Sci. U.S.A., 98: 8850-8855, 2001.

Dishman R.K., Berthoud H.R., Booth F.W., Cotman C.W., Edgerton V.R., Fleshner M.R., Gandevia S.C., Gomez-Pinilla F., Greenwood B.N., Hillman C.H., Kramer A.F., Levin B.E., Moran T.H., Russo-Neustadt A.A., Salamone J.D., Van Hoomissen J.D., Wade C.E., York D.A., Zigmond M.J. Neurobiology of exercise. Obesity (Silver Spring), 14: 345-356, 2006.

Eisele Y.S., Obermüller U., Heilbronner G., Baumann F., Kaeser S.A., Wolburg H., Walker L.C., Staufenbiel M., Heikenwalder M., Jucker M. Peripherally applied Abeta-containing inoculates induce cerebral beta-amyloidosis. Science, 330: 980-982, 2010.

Federico A., Cardaioli E., Da Pozzo P., Formichi P., Gallus G.N., Radi E. Mitochondria, oxidative stress and neurodegeneration. J. Neurol. Sci., 322: 254-262, 2012.

Feng Y., Wang X. Antioxidant therapies for Alzheimer's disease. Oxid. Med. Cell. Longev., 2012: 472932, 2012.

Foulds P.G., Mitchell J.D., Parker A., Turner R., Green G., Diggle P., Hasegawa M., Taylor M., Mann D., Allsop D. Phosphorylated $\alpha$-synuclein can be detected in blood plasma and is potentially a useful biomarker for Parkinson's disease. FASEB J, 25: 4127-4137, 2011.

Fulda S., Gorman A.M., Hori O., Samali A. Cellular stress responses: cell survival and cell death. Int. J. Cell. Biol., 2010: 214074, 2010.

Gandhi S., Abramov A.Y. Mechanism of oxidative stress in neurodegeneration. Oxid. Med. Cell. Longev., 2012: 428010, 2012.

Garlind A., Brauner A., Höjeberg B., Basun H., Schultzberg M. Soluble interleukin-1 receptor type II levels are elevated in cerebrospinal fluid in Alzheimer's disease patients. Brain Res., 826: 112-116, 1999.
Ghersi-Egea J.F., Gorevic P.D., Ghiso J., Frangione B., Patlak C.S., Fenstermacher J.D. Fate of cerebrospinal fluid-borne amyloid beta-peptide: rapid clearance into blood and appreciable accumulation by cerebral arteries. J. Neurochem., 67: 880-883, 1996.

Giacomelli C., Daniele S., Martini C. Potential biomarkers and novel pharmacological targets in protein aggregation-related neurodegenerative diseases. Biochem. Pharmacol., 131: 1-15, 2017.

Goedert M., Spillantini M.G., Del Tredici K., Braak H. 100 years of Lewy pathology. Nat. Rev. Neurol., 9: 13-24, 2013.

Growdon J.H. Biomarkers of Alzheimer disease. Arch. Neurol., 56: 281-283, 1999.

Hamer P., Slocombe B. The psychophysical and heart rate relationship between treadmill and deep-water running. Aust. J. Physiother., 43: 265-271, 1997.

Hampel H., Buerger K., Kohnken R., Teipel S.J., Zinkowski R., Moeller H.J., Rapoport S.I., Davies P. Tracking of Alzheimer's disease progression with cerebrospinal fluid tau protein phosphorylated at threonine 231. Ann. Neurol., 49: 545-546, 2001.

Head D., Bugg J.M., Goate A.M., Fagan A.M., Mintun M.A., Benzinger T., Holtzman D.M., Morris J.C. Exercise Engagement as a Moderator of the Effects of APOE Genotype on Amyloid Deposition. Arch. Neurol., 69: 636-643, 2012.

Hindin S.B., Zelinski E.M. Extended practice and aerobic exercise interventions benefit untrained cognitive outcomes in older adults: a meta-analysis. J. Am. Geriatr. Soc., 60: 136-141, 2012.

Hock C., Heese K., Müller-Spahn F., Huber P., Riesen W., Nitsch R.M., Otten U. Increased CSF levels of nerve growth factor in patients with Alzheimer's disease. Neurology, 54: 2009-2011, 2000.

Ienco E.C., Lo Gerfo A., Carlesi C., Orsucci D., Ricci G., Mancuso M., Siciliano G. Oxidative stress treatment for clinical trials in neurodegenerative diseases. J. Alzheimers Dis, 24: 111-126, 2011.

Jakowec M.W., Wang Z., Holschneider D., Beeler J., Petzinger G.M. Engaging cognitive circuits to promote motor recovery in degenerative disorders. exercise as a learning modality. J. Hum. Kinet., 52: 35-51, 2016.

Johnson R.A., Mitchell G.S. Exercise-induced changes in hippocampal brain-derived neurotrophic factor and neurotrophin-3: effects of rat strain. Brain Res., 983: 108-114, 2003.

Kawarabayashi T., Younkin L.H., Saido T.C., Shoji M., Ashe K.H., Younkin S.G. Age-dependent 
changes in brain, CSF, and plasma amyloid (beta) protein in the Tg2576 transgenic mouse model of Alzheimer's disease. J. Neurosci., 21: 372-381, 2001.

Kiko T., Nakagawa K., Satoh A., Tsuduki T., Furukawa K., Arai H., Miyazawa T. Amyloid $\beta$ levels in human red blood cells. PLoS One, 7: e49620, 2012.

Kim G.H., Kim J.E., Rhie S.J., Yoon S. The Role of Oxidative Stress in Neurodegenerative Diseases. Exp. Neurobiol., 24: 325-340, 2015.

Klein W.L., Stine W.B., Teplow D.B. Small assemblies of unmodified amyloid beta-protein are the proximate neurotoxin in Alzheimer's disease. Neurobiol. Aging, 25: 569-580, 2004.

Kramer A.F., Colcombe S.J., McAuley E., Eriksen K.I., Scalf P., Jerome G.J., Marquez D.X., Elavsky S., Webb A.G. Enhancing brain and cognitive function of older adults through fitness training. $J$. Mol. Neurosci., 20: 213-221, 2003.

Kwok J.Y., Choi K.C., Chan H.Y. Effects of mind-body exercises on the physiological and psychosocial well-being of individuals with Parkinson's disease: A systematic review and meta-analysis. Complement. Ther. Med., 29: 121131, 2016.

La Regina G., Bai R., Rensen W.M., Di Cesare E., Coluccia A., Piscitelli F., Famiglini V., Reggio A., Nalli M., Pelliccia S., Da Pozzo E., Costa B., Granata I., Porta A., Maresca B., Soriani A., Iannitto M.L., Santoni A., Li J., Miranda Cona M., Chen F., Ni Y., Brancale A., Dondio G., Vultaggio S., Varasi M., Mercurio C., Martini C., Hamel E., Lavia P., Novellino E., Silvestri R. Toward highly potent cancer agents by modulating the C-2 group of the arylthioindole class of tubulin polymerization inhibitors. J. Med. Chem., 56: 123$149,2013$.

Larson E.B., Wang L., Bowen J.D., McCormick W.C., Teri L., Crane P., Kukull W. Exercise is associated with reduced risk for incident dementia among persons 65 years of age and older. Ann. Intern. Med., 144: 73-81, 2006.

Larson M.E., Sherman M.A., Greimel S., Kuskowski M., Schneider J.A., Bennett D.A., Lesné S.E. Soluble $\alpha$-synuclein is a novel modulator of Alzheimer's disease pathophysiology. J. Neurosci., 32: 10253-10266, 2012.

Laurin D., Verreault R., Lindsay J., MacPherson K., Rockwood. K. Physical activity and risk of cognitive impairment and dementia in elderly persons. Arch. Neurol., 58: 498-504, 2001.
Lazarov O., Robinson J., Tang Y.P., Hairston I.S., KoradeMirnics Z., Lee V.M., Hersh L.B., Sapolsky R.M., Mirnics K., Sisodia S.S. Environmental enrichment reduces Abeta levels and amyloid deposition in transgenic mice. Cell, 120: 701-713, 2005.

Lee V.M., Giasson B.I., Trojanowski J.Q. More than just two peas in a pod: common amyloidogenic properties of tau and alpha-synuclein in neurodegenerative diseases. Trends Neurosci., 27: 129-134, 2004.

Liang K.Y., Mintun M.A., Fagan A.M., Goate A.M., Bugg J.M., Holtzman D.M., Morris J.C., Head D. Exercise and Alzheimer's disease biomarkers in cognitively normal older adults. Ann. Neurol., 68: 311-318, 2010.

Luk K.C., Kehm V., Carroll J., Zhang B., O’Brien P., Trojanowski J.Q., Lee V.M. Pathological $\alpha$-synuclein transmission initiates Parkinson-like neurodegeneration in nontransgenic mice. Science, 338: 949-953, 2012.

Marsh S.E., Blurton-Jones. M. Examining the mechanisms that link $\beta$-amyloid and $\alpha$-synuclein pathologies. Alzheimers Res. Ther., 4: 11, 2012.

Mattson M.P., Magnus. T. Ageing and neuronal vulnerability. Nat. Rev. Neurosci., 7: 278-294, 2006.

Maurer K., Volk S., Gerbaldo H. Auguste D and Alzheimer's disease. Lancet, 349: 1546-1549, 1997.

Mohanty J.G., Nagababu E., Rifkind J.M. Red blood cell oxidative stress impairs oxygen delivery and induces red blood cell aging. Front. Physiol., 5: 84, 2014.

Navarro A., Boveris A. Brain mitochondrial dysfunction in aging, neurodegeneration, and Parkinson's disease. Front. Aging Neurosci., 2: 34, 2010.

Paillard T., Rolland Y., de Souto Barreto P. Protective Effects of Physical Exercise in Alzheimer's Disease and Parkinson's Disease: A Narrative Review. J. Clin. Neurol., 11: 212-219, 2015.

Pandey K.B., Rizvi S.I. Markers of oxidative stress in erythrocytes and plasma during aging in humans. Oxid. Med. Cell. Longev. 3: 2-12, 2010.

Parihar M.S., Hemnani T. Alzheimer's disease pathogenesis and therapeutic interventions. J. Clin. Neurosci., 11: 456-467, 2004.

Patten D.A., Germain M., Kelly M.A., Slack R.S. Reactive oxygen species: stuck in the middle of neurodegeneration. J. Alzheimers Dis., 20: 357367, 2010.

Pesini P., Pérez-Grijalba V., Monleón I., Boada M., Tárraga L., Martínez-Lage P., San-José I., Sarasa 
M. Reliable Measurements of the $\beta$-Amyloid Pool in Blood Could Help in the Early Diagnosis of AD. Int. J. Alzheimers Dis., 2012: 604141, 2012.

Poon H.F., Calabrese V., Scapagnini G., Butterfield D.A. Free radicals and brain aging. Clin. Geriatr. Med., 20: 329-359, 2004.

Power G.A., Dalton B.H., Rice C.L. Human neuromuscular structure and function in old age: A brief review. J. Sport Health Sci., 2: 215-226, 2013.

Price J.L., McKeel D.W., Buckles V.D., Roe C.M., Xiong C., Grundman M., Hansen L.A., Petersen R.C., Parisi J.E., Dickson D.W., Smith C.D., Davis D.G., Schmitt F.A., Markesbery W.R., Kaye J., Kurlan R., Hulette C., Kurland B.F., Higdon R., Kukull W., Morris J.C. Neuropathology of nondemented aging: presumptive evidence for preclinical Alzheimer disease. Neurobiol. Aging, 30: 1026-1036, 2009.

Radak Z., Hart N., Sarga L., Koltai E., Atalay M., Ohno H., Boldogh I. Exercise plays a preventive role against Alzheimer's disease. J. Alzheimers Dis., 20: 777-783, 2010.

Radak Z., Suzuki K., Higuchi M., Balogh L., Boldogh I., Koltai E. Physical exercise, reactive oxygen species and neuroprotection. Free Radic. Biol. Med., 98: 187-196, 2016.

Reiber H. Proteins in cerebrospinal fluid and blood: barriers, CSF flow rate and source-related dynamics. Restor. Neurol. Neurosci., 21: 79-96, 2003.

Ridley R.M., Baker H.F., Windle C.P., Cummings R.M. Very long term studies of the seeding of beta-amyloidosis in primates. J. Neural Transm. (Vienna), 113: 1243-1251, 2006.

Román G.C. Neuroepidemiology of amyotrophic lateral sclerosis: clues to aetiology and pathogenesis. J. Neurol. Neurosurg. Psychiatry, 61: 131-137, 1996.

Singh S. Antioxidants as a preventive therapeutic option for age related neurodegenerative diseases. Ther. Targets. Neurol. Dis., 2: e592, 2015.
Tapia-Rojas C., Aranguiz F., Varela-Nallar L., Inestrosa N.C. Voluntary Running Attenuates Memory Loss, Decreases Neuropathological Changes and Induces Neurogenesis in a Mouse Model of Alzheimer's Disease. Brain Pathol., 26: 62-74, 2016.

Trojanowski J.Q. Emerging Alzheimer's disease therapies: focusing on the future. Neurobiol. Aging, 23: 985-990, 2002.

Ugalde C.L., Finkelstein D.I., Lawson V.A., Hill A.F. Pathogenic mechanisms of prion protein, amyloid- $\beta$ and $\alpha$-synuclein misfolding: the prion concept and neurotoxicity of protein oligomers. $J$. Neurochem., 139: 162-180, 2016.

Voss M.W., Vivar C., Kramer A.F., van Praag H. Bridging animal and human models of exerciseinduced brain plasticity. Trends Cogn. Sci., 17: 525-544, 2013.

Wang X., Yu S., Li F., Feng T. Detection of $\alpha$-synuclein oligomers in red blood cells as a potential biomarker of Parkinson's disease. Neurosci. Lett., 599: 115-119, 2015.

Weuve J., Kang J.H., Manson J.E., Breteler M.M., Ware J.H., Grodstein F. Physical activity, including walking, and cognitive function in older women. JAMA, 292: 1454-1461, 2004.

Winter B., Breitenstein C., Mooren F.C., Voelker K., Fobker M., Lechtermann A., Krueger K., Fromme A., Korsukewitz C., Floel A., Knecht S. High impact running improves learning. Neurobiol. Learn. Mem., 87: 597-609, 2007.

Zhang L., Zhao B., Yew D.T., Kusiak J.W., Roth G.S. Processing of Alzheimer's amyloid precursor protein during $\mathrm{H} 2 \mathrm{O} 2$-induced apoptosis in human neuronal cells. Biochem. Biophys. Res. Commun., 235: 845-848, 1997.

Zhao Y. And Zhao B. Oxidative stress and the pathogenesis of Alzheimer's disease. Oxid. Med. Cell. Longev., 2013: 316523, 2013.

Zlokovic B.V. Clearing amyloid through the bloodbrain barrier. J. Neurochem., 89: 807-181, 2004. 